\title{
Introduction of medication review and medication report in Swedish hospital and primary care, using a theory-based implementation strategy
}

\author{
Siw Carlfjord ${ }^{1 *}$ (D) Eva Malmberg ${ }^{2}$ and Carina Skoglund ${ }^{3}$
}

\begin{abstract}
Background: The development of routines regarding medication is important to avoid medication-related harm. Medication review and medication reports have earlier been found to be effective, but their implementation is not always successful. The aim of this study was to evaluate the introduction of medication review/medication report in hospital and primary care, in terms of perceptions of the implementation strategy, adoption and sustainability, in one Swedish county.

Methods: The study included 105 clinics. Data was collected from interviews with managers immediately after implementation, survey data and registry data collected five years later. Quantitative data was analysed using nonparametric statistical tests. Open-ended questions were analysed with qualitative methods.

Results: The implementation activities were found satisfying, and managers were satisfied with their own influence over the process. After five years medication review and medication reports were reported mainly implemented by the managers. Facilitating factors reported were routines, staff influence, dedication, reminders, and a stable workforce, while hindering factors reported were organizational factors, less commitment and flaws in reporting. Registry data showed that performance of medication review was very limited in primary care. In hospital care medication review was registered in about one fifth of the patients, while medication reports, only relevant for hospital care, was registered in half of the patients.

Conclusions: The managers' perceptions of the implementation process were mainly positive, and they found the new practices of medication review/medication report implemented. Implementation success, however, was not supported by registry data, showing the need for reliable outcome measures for implementation.
\end{abstract}

Keywords: Quality improvement, Medication report, Medication review, Implementation

\footnotetext{
* Correspondence: siw.carlfjord@liu.se

${ }^{1}$ Department of Health, Medicine and Caring Sciences, Division of Community and Heath, Linköping University, SE-58183 Linköping, Sweden

Full list of author information is available at the end of the article
}

(c) The Author(s). 2020 Open Access This article is licensed under a Creative Commons Attribution 4.0 International License, which permits use, sharing, adaptation, distribution and reproduction in any medium or format, as long as you give appropriate credit to the original author(s) and the source, provide a link to the Creative Commons licence, and indicate if changes were made. The images or other third party material in this article are included in the article's Creative Commons licence, unless indicated otherwise in a credit line to the material. If material is not included in the article's Creative Commons licence and your intended use is not permitted by statutory regulation or exceeds the permitted use, you will need to obtain permission directly from the copyright holder. To view a copy of this licence, visit http://creativecommons.org/licenses/by/4.0/ The Creative Commons Public Domain Dedication waiver (http://creativecommons.org/publicdomain/zero/1.0/) applies to the data made available in this article, unless otherwise stated in a credit line to the data. 


\section{Background}

The implementation of new methods with the purpose of improving care, patient safety and patient outcomes is highly prioritized in health care organizations all over the world [1]. Nevertheless many innovative interventions or suggested improvements have difficulties in being spread, adopted and sustained in practice. One area, often mentioned to be in need of improvement, is the development of routines regarding medication [2, 3]. Medicines are the most commonly used therapies in health care, new drugs are continuously developed and the consumption is increasing [4]. Generally drug treatment has beneficial effects, but medication therapy may also be associated with negative health outcomes. If medicines are prescribed or used inappropriately, patient safety can be compromised, treatment will result ineffective and it can ultimately lead to medication-related problems $[5,6]$.

A method suggested in order to reduce medicationrelated harm is the systematic assessment of the individual patient's pharmacotherapy, a process called medication review [7]. At admittance to hospital, or at a general practitioner consultation in primary care, the patient's current medications are identified and compared to the registered list, unintended discrepancies are reconciled and the list is updated [8]. Medication reviews have been put into practice in many countries, however, the implementation into routine health care has been challenging [9]. At discharge from hospital a medication report is proposed to be handed over to the patient, in order to reduce patient-related mistakes regarding medication distribution at home $[10,11]$.

In Sweden the National Board of Health and Welfare introduced medication review, and also medication reports nationally in 2012, with the aim of reducing inappropriate prescribing and preventable medicationrelated problems [12]. Patients aged 75 years or older with at least five prescribed medications are entitled to receive medication review once a year in primary care, and when admitted to hospital. Medication reports should be provided at discharge from hospital. In Östergötland county the local health authorities decided to apply a broader scope in that medication review must be conducted for all patients irrespective of age or number of medications. Implementation efforts were put into practice in 2013 with the intention to establish "uniform procedures in order to reduce the risk of avoidable medication-related problems" [13]. The strategy used for the implementation was closely linked to the Quality Implementation Framework described by Meyers et al. [14], and is described in detail in the Methods section.

Proctor et al. suggest that when studies evaluating implementation are reported, the strategies used should be thoroughly labelled and described, and operational definitions should be provided [15]. In the present study we have considered these suggestions and try to report the implementation processes in sufficient detail, combining the Proctor et al. suggestions with the Quality Implementation Framework [14, 15].

The aim of this study was to evaluate the introduction of medication review/medication report in hospital and primary care in one Swedish county, in terms of perceptions of the implementation strategy, adoption and sustainability.

\section{Methods}

This study applies a mainly quantitative design, including data from structured interviews immediately after the implementation activities, and survey data collected five years later. Cross-sectional registry data from one month during the fifth year after initial implementation were also included. The study is reported according to the Standards for QUality Improvement Reporting Excellence (SQUIRE) 2.0 checklist [16].

\section{Setting}

The study was performed in the county of Östergötland, Sweden, and includes all the 105 clinics operating in the area, hospital and primary care, both private and public. In Sweden health care is mainly publicly funded, and the private clinics included operate with public funding according to local agreements with the authorities. The county of Östergötland has approximately 450,000 inhabitants and has been found to be representative for the whole country in terms of age distribution, employment rates and proportion of rural and urban areas. The health care authorities divide the county into Western, Eastern and Central Östergötland, with one hospital and a number of primary health care centres operating in each part.

\section{Implementation strategy}

The strategy used for the implementation of medication reviews in Östergötland county was closely linked to the Quality Implementation Framework described by Meyers et al., consisting of four phases and 14 critical steps [14]. The implementation activities are described in Table 1, with references to the framework. During the implementation phase there were challenges in terms of lack of continuity in one of the three country parts, due to staff turnover.

\section{Data collection}

Data were collected when the implementation activities were completed, and five years later. Registry data based on the reporting of medication reviews and medication reports were collected from one month during the fifth year. 
Table 1 Implementation strategy based on the Quality Implementation Framework (Meyers et al. 2012)

\begin{tabular}{|c|c|c|c|c|}
\hline \multicolumn{3}{|c|}{ Quality Implementation Framework (QIF) } & \multicolumn{2}{|c|}{ Application in project } \\
\hline Phase & Step category & QIF step according to phase & Definition & Operationalization \\
\hline \multirow[t]{6}{*}{$\begin{array}{l}\text { Phase One: Initial } \\
\text { considerations } \\
\text { regarding the host } \\
\text { setting }\end{array}$} & $\begin{array}{l}\text { Assessment } \\
\text { strategies }\end{array}$ & $\begin{array}{l}1-3 \text {. Conducting a needs and } \\
\text { resources assessment, a fit } \\
\text { assessment, and a capacity/ } \\
\text { readiness assessment }\end{array}$ & $\begin{array}{l}\text { Initial } \\
\text { assessment }\end{array}$ & $\begin{array}{l}\text { Initial assessments were not considered applicable, } \\
\text { as the initiative for implementing Medication } \\
\text { Review and Medication Report was a } \\
\text { governmental decision based on scientific findings. }\end{array}$ \\
\hline & $\begin{array}{l}\text { Decisions about } \\
\text { adaptation }\end{array}$ & 4. Possibility for adaptation & Adaptation & $\begin{array}{l}\text { All units were allowed to decide on local routines } \\
\text { in addition to the general routine that was } \\
\text { implemented. }\end{array}$ \\
\hline & \multirow[t]{4}{*}{$\begin{array}{l}\text { Capacity- } \\
\text { building } \\
\text { strategies }\end{array}$} & $\begin{array}{l}\text { 5. Obtaining explicit buy-in from } \\
\text { critical stakeholders }\end{array}$ & Decision & $\begin{array}{l}\text { A decision of systematic implementation of } \\
\text { Medication Review and Medication Report in } \\
\text { Health Care in the county council of Östergötland, } \\
\text { was made at the county council management } \\
\text { level. }\end{array}$ \\
\hline & & $\begin{array}{l}\text { 6. Building general/organizational } \\
\text { capacity }\end{array}$ & Steering group & $\begin{array}{l}\text { A steering group including the head health care } \\
\text { manager, medical directors and health care } \\
\text { managers from different sectors was recruited to } \\
\text { supervise the implementation. }\end{array}$ \\
\hline & & 7. Staff recruitment/maintenance & Staff & $\begin{array}{l}\text { Recruitment of a project manager, and delegates } \\
\text { representing the three parts of the county, the } \\
\text { department of clinical pharmacy, and medical } \\
\text { doctors from primary care and hospital care. An } \\
\text { implementation researcher was also invited to the } \\
\text { group. }\end{array}$ \\
\hline & & $\begin{array}{l}\text { 8. Effective pre-innovation staff } \\
\text { training }\end{array}$ & $\begin{array}{l}\text { Guideline } \\
\text { available }\end{array}$ & $\begin{array}{l}\text { Guidelines for Medication Review and Medication } \\
\text { Report were developed and made available for } \\
\text { staff at the internal website. }\end{array}$ \\
\hline \multirow{2}{*}{$\begin{array}{l}\text { Phase Two: Creating } \\
\text { a structure for } \\
\text { implementation }\end{array}$} & \multirow{2}{*}{$\begin{array}{l}\text { Structural } \\
\text { features for } \\
\text { implementation }\end{array}$} & 9. Creating implementation teams & Teams & $\begin{array}{l}\text { One implementation agent }(\mathrm{IA}) \text { in each part of the } \\
\text { county was assigned to lead the activities. }\end{array}$ \\
\hline & & $\begin{array}{l}\text { 10. Developing an implementation } \\
\text { plan }\end{array}$ & $\begin{array}{l}\text { Implementation } \\
\text { plan / } \\
\text { Communication } \\
\text { plan }\end{array}$ & $\begin{array}{l}\text { A local implementation plan was developed, } \\
\text { including the following steps:IA contacts the } \\
\text { manager, local timetable is set } \\
\text { IA meets all physicians at the unit, a "physician in } \\
\text { charge" is assignedSecond physician meeting, } \\
\text { including information about documentation } \\
\text { The manager is in charge of informing the nurse } \\
\text { group. }\end{array}$ \\
\hline \multirow{3}{*}{$\begin{array}{l}\text { Phase Three: } \\
\text { Ongoing structure } \\
\text { once } \\
\text { implementation } \\
\text { begins }\end{array}$} & \multirow{3}{*}{$\begin{array}{l}\text { Ongoing } \\
\text { implementation } \\
\text { support } \\
\text { strategies }\end{array}$} & $\begin{array}{l}\text { 11. Technical assistance/coaching/ } \\
\text { supervision }\end{array}$ & $\begin{array}{l}\text { Electronic } \\
\text { medical record } \\
\text { system }\end{array}$ & $\begin{array}{l}\text { The medical record system was developed in order } \\
\text { to facilitate performance and reporting of } \\
\text { Medication Reviews and Medication Reports. }\end{array}$ \\
\hline & & 12. Process evaluation & $\begin{array}{l}\text { Post- } \\
\text { implementation } \\
\text { interview }\end{array}$ & $\begin{array}{l}\text { Structured interviews with managers when all the } \\
\text { facilitating activities had been completed }\end{array}$ \\
\hline & & 13. Supportive feedback mechanism & Feed-back & $\begin{array}{l}\text { Follow-up data on unit level was made available to } \\
\text { all managers, intended to increase adoption and } \\
\text { sustainability }\end{array}$ \\
\hline $\begin{array}{l}\text { Phase Four: } \\
\text { Improving future } \\
\text { applications }\end{array}$ & & 14. Learning from experience & $\begin{array}{l}\text { Follow-up } \\
\text { survey }\end{array}$ & $\begin{array}{l}\text { At follow-up after five years, facilitating and imped- } \\
\text { ing factors were identified, based on open-ended } \\
\text { questions }\end{array}$ \\
\hline
\end{tabular}

\section{Interviews}

Structured interviews following an interview guide developed for the project (Additional file 1), were performed with the department managers as the last step of the implementation activity. A meeting was arranged with the manager, the questions were put orally, and a protocol was completed by the interviewer. The questions concerned perceptions of the implementation activities, the support from the implementation team, if practice had changed and the managers view of how medication reviews and medication reports were perceived by physicians and other staff members. Questions were mainly multiple choice, but with an option to make comments.

\section{Survey}

Five years after the first interview, in spring 2019, the department managers were approached by e-mail and asked to fill out a survey regarding the implementation 
of medication reviews/medication reports at their department. The survey was distributed to the current manager, meaning that it could be another person than the one who was interviewed in the first place. Survey questions were developed for the specific study, based on the former interview questions, and were discussed with county council representatives and patient safety experts to obtain face validity. The survey also included open ended questions regarding facilitating factors where medication review/medication reports had been successfully implemented, and perceived hindering factors where it was partly or not at all implemented. The questionnaire can be found in Additional file 2.

\section{Registry data}

Data on performance are automatically transferred from medical records, and stored in the county council database. Data were available for a majority of the participating clinics, and were used to quantitatively evaluate how medication review and medication report is actually performed at the clinics. As data showed very little fluctuation over time, cross-sectional data from one month in year five, coinciding with the follow-up survey, were used for the analysis.

\section{Data analysis}

Quantitative data from the structured interviews and the survey, as well as registry data. Were analysed using the Statistical Package for the Social Sciences (SPSS) version 24. Data from the different county parts were compared using the Mann Whitney $U$ test, and changes over time were analysed using the Chi-Square test. Correlations were calculated using Spearman's rho.

Data from the open ended questions in the survey were analysed according to the method Qualitative Content Analysis with a deductive approach, so called Directed Content Analysis [17]. The statements were categorized according to the four domains Context, Adopters, Implementation object and Implementation strategy, often used as determinants for successful implementation in the description and analysis of implementation processes $[18,19]$.

\section{Results}

\section{Response rates}

For the follow-up interview 105 managers were contacted, and $90(86 \%)$ of these agreed to participate in the interview. The survey distributed five years later was sent to the same 105 clinics, and yielded answers from 54 clinics (51\%), (32 hospital care, 22 primary care). Registry data was available from 61 of the participating clinics (29 hospital care, 32 primary care). Data from all data sources was available for 31 clinics (21 hospital care, 10 primary care).

\section{Results from follow-up interviews}

Managers perceptions of the implementation strategy and activities

Table 2 shows the managers' opinions about the implementation. Overall satisfaction with the implementation was reported by most of the participating managers, and a majority reported that the support from the implementation team had been good. There was, however a difference between the three county parts, A, B and C, with managers in A less satisfied than the others. No or small influence over the implementation process was reported by $80 \%$, but $81 \%$ of the responding managers were satisfied with the influence they had. Less satisfaction with the influence was found in county part A. County part A was the one that had problems with staff turnover during the implementation process.

\section{Managers perceptions of staff attitudes regarding medication review/report}

Among the managers, 53\% reported that the physicians were positive to medication review/report, and $48 \%$ found other staff groups positive.

\section{Change in practice}

A change in practice was reported by $61 \%$ of the managers, 33\% reported no change, and $6 \%$ did not answer the question.

\section{Sustainability according to survey data}

After five years, $46 \%$ of the responding managers considered medication review implemented at their clinic, and another $48 \%$ reported it to be partly implemented. Medication reports, relevant only for hospital clinics, was considered implemented at $42 \%$ of these clinics, and partly implemented at another $35 \%$ of the clinics. No differences could be found according to part of the county.

After five years the attitudes among physicians and staff were reported slightly, but not significantly, more positive than at the time for the follow-up interview, as displayed in Table 3.

\section{Facilitating and hindering factors}

Facilitating or hindering factors were described by the managers in the five year survey. The results are presented according to the categories Context, Adopters, Implementation object and Implementation strategy.

\section{Factors perceived to have facilitated implementation of medication review/report}

Regarding context, structural factors such as a stable workforce and a reasonable work load, were mentioned as facilitating factors. For medication review the presence of a pharmacist was also considered important. 
Table 2 Manager opinions about implementation, implementation support and influence

\begin{tabular}{|c|c|c|c|c|c|}
\hline & $\begin{array}{l}\text { Total } \\
\text { n (\%) }\end{array}$ & $\begin{array}{l}\text { County part A } \\
\mathrm{n}(\%)\end{array}$ & $\begin{array}{l}\text { County } \\
\text { part B } \\
\text { n (\%) }\end{array}$ & $\begin{array}{l}\text { County } \\
\text { part C } \\
\text { n }(\%)\end{array}$ & Difference between county parts* \\
\hline $\begin{array}{l}\text { Are you satisfied with how medication review/medication } \\
\text { report was implemented at your clinic/centre? }\end{array}$ & & & & & $p>0.05$ \\
\hline Totally satisfied & $34(39)$ & $7(24)$ & $20(44)$ & $7(50)$ & \\
\hline Quite satisfied & $44(50)$ & $19(66)$ & $18(40)$ & $7(50)$ & \\
\hline Dissatisfied & $10(11)$ & $3(10)$ & $7(16)$ & 0 & \\
\hline Very dissatisfied & 0 & 0 & 0 & 0 & \\
\hline $\begin{array}{l}\text { How did you perceive the support from the } \\
\text { implementation team? }\end{array}$ & & & & & $\begin{array}{l}C>A(p<0.05) \\
B>A(p<0.01)\end{array}$ \\
\hline Good & $62(72)$ & $12(44)$ & $38(84)$ & $12(86)$ & \\
\hline Quite good & $13(15)$ & $7(26)$ & $4(9)$ & $2(14)$ & \\
\hline Quite bad & $5(6)$ & $3(11)$ & $2(4)$ & 0 & \\
\hline $\mathrm{Bad}$ & $6(7)$ & $5(18)$ & $1(2)$ & 0 & \\
\hline $\begin{array}{l}\text { Did you perceive having an opportunity to influence } \\
\text { the implementation process? }\end{array}$ & & & & & $p>0.05$ \\
\hline Totally & $5(6)$ & $1(4)$ & $2(4)$ & $2(14)$ & \\
\hline Quite much & $13(15)$ & $4(14)$ & $5(11)$ & $4(27)$ & \\
\hline Somehow & $35(40)$ & $8(29)$ & $23(50)$ & $4(27)$ & \\
\hline Not at all & $35(40)$ & $15(54)$ & $16(35)$ & $4(27)$ & \\
\hline $\begin{array}{l}\text { Are you satisfied with the influence you had over the } \\
\text { implementation process? }\end{array}$ & & & & & $\begin{array}{l}C>A(p<0.05) \\
B>A(p<0.05)\end{array}$ \\
\hline Totally satisfied & $25(35)$ & $4(17)$ & $16(43)$ & $5(50)$ & \\
\hline Quite satisfied & $33(46)$ & $12(50)$ & $16(43)$ & $5(50)$ & \\
\hline \multirow{2}{*}{$\begin{array}{l}\text { Dissatisfied } \\
\text { Very dissatisfied }\end{array}$} & $9(13)$ & $5(21)$ & $4(11)$ & 0 & \\
\hline & $4(6)$ & $3(12)$ & $1(3)$ & 0 & \\
\hline
\end{tabular}

* Calculated using the Mann-Whitney U test

Where routines were partly in place before the formal implementation was initiated, and performing medication review was considered part of the task, this was described as facilitating.

Where implementation was described as successful, staff members (the adopters), had taken part in discussions and decisions. According to the managers, staff were dedicated, had a positive attitude to performing medication review/report and found the task important. The task was also perceived as being easy to fulfil.

Regarding the strategy, the development of routines and continuous reminders was considered crucial, together with information and communication with staff. The implementation activities were found to be well balanced, and at some clinics ongoing improvement projects were also mentioned as facilitating factors.

\section{Factors perceived to have hindered implementation}

At clinics where medication review or medication report was described as partly implemented the hindering contextual factors mentioned were staff shortage, lack of time and how work was organized. Frequent changes in practice, initiated from management level, was also mentioned.

A lack of commitment regarding medication review/ report among staff members (adopters) was mentioned, but also flaws in reporting, which means that more activities were believed to be performed than what is actually reported. Regarding medication review a lack of competence among staff was also mentioned. A strategy factor mentioned was the need for continuous reminders and feed-back, which sometimes were not in place.

At some clinics medication review or medication reports was not considered relevant, as the patients are young, not severely ill, and have very few prescribed medicines. Some clinics only serve outpatients, making medication reports irrelevant.

\section{Registry data}

Registry data was available for 32 primary care clinics, and the proportion of patients who had had a medication review ranged from $0.5-12 \%$ (median8\%). Data on medication review from hospital care was available from 29 clinics, and the proportion of patients who had had a 
Table 3 Attitudes among physicians and other staff members at follow-up and after five years, as reported by managers

\begin{tabular}{|c|c|c|c|}
\hline & $\begin{array}{l}\text { Attitudes at follow- } \\
\text { up } \\
\text { n (\%) }\end{array}$ & $\begin{array}{l}\text { Attitudes after } 5 \\
\text { years } \\
\text { n (\%) }\end{array}$ & $\begin{array}{l}\text { Change in attitude over } \\
\text { time }\end{array}$ \\
\hline $\begin{array}{l}\text { How would you describe the opinion regarding medication review } \\
\text { and medication report among the physicians at your clinic/centre?* }\end{array}$ & & & $\begin{array}{l}5 \text { years }>\text { follow-up } \\
(p>0.05)\end{array}$ \\
\hline Very positive & $1(2)$ & $2(5)$ & \\
\hline Positive & $20(48)$ & $23(55)$ & \\
\hline Neither positive nor negative & $14(33)$ & $15(36)$ & \\
\hline Negative & $5(12)$ & $2(5)$ & \\
\hline Very negative & $2(5)$ & 0 & \\
\hline $\begin{array}{l}\text { How would you describe the opinion regarding medication review } \\
\text { and medication report among other staff members at your } \\
\text { clinic/centre?* }\end{array}$ & & & $\begin{array}{l}5 \text { years }>\text { follow-up } \\
(p>0.05)\end{array}$ \\
\hline Very positive & $3(8)$ & $3(8)$ & \\
\hline Positive & $15(39)$ & $24(63)$ & \\
\hline Neither positive nor negative & $19(50)$ & $11(29)$ & \\
\hline Negative & $1(3)$ & 0 & \\
\hline Very negative & 0 & 0 & \\
\hline
\end{tabular}

*Only clinics/centres where data was available from both data collections

**Calculated using the Pearson Chi-square test

medication review ranged from 1 to $97 \%$ (median 32\%). Data on medication reports was available from 26 of the hospital clinics. The proportion of patients who had received a medication report at these clinics ranged from 3 to $88 \%$ (median $58 \%$ ). Data regarding medication report is not relevant for primary care.

\section{Comparison of data from different sources Primary care}

Data from all the three data sources was available from 10 primary care clinics, and are displayed in Table 4 . The managers in primary care were positive or very positive to medication review, they were mainly satisfied with the implementation efforts, and with the support.
Six of the managers reported that medication review was successfully implemented. However, according to registry data, no clinic had a proportion higher than $8 \%$ of patients having a medication review. Managers' report on implementation did not correlate to proportion of patients having a medication review according to the register $(\mathrm{r}=0.11 . p=0.8)$.

\section{Hospital care}

Data regarding medication review from all the three data sources was available from 20 hospital care clinics, and are displayed in Table 5 . The vast majority of the managers stated that they were satisfied with the implementation efforts and the support provided, and 17 of the 20

Table 4 Medication review in primary care, sorted according to proportion of patients with medication review

\begin{tabular}{|c|c|c|c|c|c|}
\hline Unit* & $\begin{array}{l}\text { Satisfied with } \\
\text { implementation }\end{array}$ & $\begin{array}{l}\text { Opinion about } \\
\text { support }^{1}\end{array}$ & $\begin{array}{l}\text { Medication review } \\
\text { implemented }^{2}\end{array}$ & $\begin{array}{l}\text { Opinion about medication } \\
\text { report/review }\end{array}$ & $\begin{array}{l}\text { Proportion with medication } \\
\text { review }(\%)^{3}\end{array}$ \\
\hline P1 & Quite satisfied & Good & Partly & Very positive & 1 \\
\hline P2 & Quite satisfied & Quite bad & Yes & Positive & 1 \\
\hline P3 & Totally satisfied & Good & Partly & Very positive & 1 \\
\hline P4 & Quite satisfied & Quite good & Yes & Positive & 2 \\
\hline P5 & Totally satisfied & Good & Yes & Positive & 3 \\
\hline P6 & Not satisfied & Good & Yes & Positive & 4 \\
\hline P7 & Totally satisfied & Good & Partly & Very positive & 4 \\
\hline P8 & Quite satisfied & Good & Yes & Positive & 7 \\
\hline P9 & Totally satisfied & Good & Partly & Very positive & 7 \\
\hline P10 & Totally satisfied & Good & Yes & Very positive & 8 \\
\hline
\end{tabular}

${ }^{1}$ Data from follow-up interview ${ }^{2}$ Data from 5 year survey ${ }^{3}$ Data from county register

*P1-P10 = Primary Care Unit 1-10 
Table 5 Medication review and medication report in hospital care, sorted according to proportion of patients with medication review

\begin{tabular}{|c|c|c|c|c|c|c|c|}
\hline Unit* & $\begin{array}{l}\text { Satisfied with } \\
\text { imple- } \\
\text { mentation }{ }^{1}\end{array}$ & $\begin{array}{l}\text { Opinion } \\
\text { about } \\
\text { support }^{1}\end{array}$ & $\begin{array}{l}\text { Medication } \\
\text { review } \\
\text { implemented }^{2 * *}\end{array}$ & $\begin{array}{l}\text { Opinion about } \\
\text { medication report/ } \\
\text { review }^{2}\end{array}$ & $\begin{array}{l}\text { Proportion with } \\
\text { medication review } \\
(\%)^{3}\end{array}$ & $\begin{array}{l}\text { Medication } \\
\text { report } \\
\text { implemented }^{2 * *}\end{array}$ & $\begin{array}{l}\text { Proportion with } \\
\text { medication report } \\
(\%)^{3}\end{array}$ \\
\hline $\mathrm{H} 1$ & Totally satisfied & Good & Partly & Very positive & 3 & & \\
\hline $\mathrm{H} 2$ & Quite satisfied & Good & No & $\begin{array}{l}\text { Neither positive nor } \\
\text { negative }\end{array}$ & 8 & No & 28 \\
\hline $\mathrm{H} 3$ & Totally satisfied & - & Partly & Very positive & 9 & Partly & 6 \\
\hline $\mathrm{H} 4$ & Totally satisfied & Good & Yes & Very positive & 9 & Yes & 18 \\
\hline H5 & Quite satisfied & Bad & Yes & Positive & 12 & Yes & 39 \\
\hline H6 & Totally satisfied & Quite good & Yes & Positive & 13 & & \\
\hline $\mathrm{H} 7$ & Totally satisfied & Good & Yes & Very positive & 25 & Yes & 69 \\
\hline $\mathrm{H} 8$ & Quite satisfied & Quite good & Yes & Positive & 28 & Yes & 64 \\
\hline H9 & Not satisfied & Good & Yes & Very positive & 29 & Yes & 76 \\
\hline $\mathrm{H} 10$ & Quite satisfied & Quite good & Yes & Very positive & 32 & & \\
\hline $\mathrm{H} 11$ & Quite satisfied & Quite good & Partly & Positive & 37 & & \\
\hline $\mathrm{H} 12$ & Quite satisfied & Good & Partly & $\begin{array}{l}\text { Neither positive nor } \\
\text { negative }\end{array}$ & 38 & & \\
\hline $\mathrm{H} 13$ & Totally satisfied & Good & Yes & $\begin{array}{l}\text { Neither positive nor } \\
\text { negative }\end{array}$ & 45 & Yes & 14 \\
\hline $\mathrm{H} 14$ & Totally satisfied & Quite good & Yes & Very positive & 46 & Yes & 73 \\
\hline H15 & Totally satisfied & Good & Yes & Positive & 58 & Partly & 58 \\
\hline H16 & Quite satisfied & Good & Yes & Very positive & 72 & Yes & 69 \\
\hline $\mathrm{H} 17$ & Totally satisfied & Good & Partly & Positive & 76 & Partly & 4 \\
\hline H18 & Quite satisfied & Good & Yes & Positive & 91 & Yes & 76 \\
\hline H19 & Quite satisfied & Bra & Yes & Positive & 94 & Yes & 13 \\
\hline $\mathrm{H} 2 \mathrm{O}$ & Quite satisfied & - & Partly & Very positive & 97 & Yes & 77 \\
\hline $\mathrm{H} 21$ & Quite satsfied & Good & Partly & $\begin{array}{l}\text { Neither positive nor } \\
\text { negative }\end{array}$ & - & No & 75 \\
\hline
\end{tabular}

${ }^{1}$ Data from follow-up interview ${ }^{2}$ Data from 5 year survey ${ }^{3}$ Data from county register ${ }^{*} \mathrm{H} 1-\mathrm{H} 21=$ Hospital clinic $1-21$

**Medication review: Data from 20 units, Medication report: Data from 16 units

managers stated that they were positive or very positive to medication review/report. They also stated that medication review was implemented (13) or partly implemented (6). The correlation between the managers' report of implementation and the proportion of patients registered to have had a medication review was, however, very weak and not significant $(r=0.13, p=0.6)$. Nor did the managers opinion about medication review/ report and registry data correlate.

Regarding medication report, data from all three data sources was available from 16 clinics displayed in Table 5. Most of the managers stated that medication review was implemented (11) or partly implemented (3).

\section{Discussion}

This study showed that the implementation activities provided when medication review and medication report was introduced were found satisfying by the managers, who also reported satisfaction with their own influence over the process. Five years after the initial implementation, medication review and medication reports were reported implemented by the managers in almost half of the clinics where relevant. Facilitating factors reported were routines, staff influence, dedication, reminders, and a stable workforce, while hindering factors reported were organizational factors, less commitment, flaws in reporting, and the absence of reminders or feed-back.

From the registers, however, the medical records show that performance of medication review was very limited in primary care. In hospital care medication review was registered in about one fifth of the patients, while medication reports, only relevant for hospital care, was registered in half of the patients.

The application of implementation theory in the planning and performance of the implementation activities in this study worked out well. The managers were 
satisfied with how the process had been facilitated by the implementation team, and, even though their influence over the activities was limited, they reported satisfaction also regarding influence. Former studies have shown that the implementation activities in terms of strategy and facilitation is important for implementation success $[20,21]$. Despite this, few implementation studies clearly report in what way their strategies are informed by theory, and do not describe the strategies used [15].

Based on the manager reporting of fully or partly implemented medication review/medication report the implementation must be considered successful. If the practise was not applied at all before implementation, and now half of the clinics report it implemented this is a success. Based on registry data implementation outcome is not that successful, with low proportions receiving medication review, but higher proportions receiving medication report where relevant. From former studies, however, we know that implementation activities seldom result in full and sustainable change. Systematic reviews evaluating different implementation strategies show small to moderate effects, with effect sizes usually 5$12 \%$ [22-24].

Barriers and facilitators for implementation have been reported in a number of studies. However, barriers and facilitators are often context-specific, and cannot easily be transferred from one context to another. In the present study a facilitator mentioned was dedication. This could also be seen in terms of motivation [25]. Intrinsic motivation, meaning that the staff member has gained an understanding about the importance of practising the new working method, can lead to a dedication for the task. At clinics where this dedication is present the implementation has been more successful than where staff attitudes are described as lack of commitment to the task.

Another facilitator mentioned was reminders, which was not part of the overarching strategy, but was used locally by the managers. Reminders have also been identified as important to achieve change in practice [26]. Staff tend to forget tasks that are added to their routines, and the practice of reminders is a way to overcome this.

A hindering factor, or rather an explanation for low reported numbers, that was mentioned by the managers was flaws in reporting. This can also be an explanation for the great discrepancy between manager reporting of medication review/medication report being implemented at their clinic, and the very low proportions of patients receiving this service according to registers. Selfreporting is known to be a measure that can be affected by social desirability [27], if the reporter knows what is expected, and reports a little more generously than what is actually true. However, if reporting to the register is not carefully performed, also the registry data will suffer from considerable limitations.

The fact that neither self-reported data, nor registry data can be totally reliable accentuates the problem with outcome measures in implementation research. A number of outcome measures have been proposed, for example by Proctor et al. suggesting Acceptability, Adoption, Appropriateness, Costs, Feasibility, Fidelity, Penetration and Sustainability to be evaluated [28]. Most of these measures, however, are depending on either self-reporting to the researchers or data registered by staff members in medical records.

The need for better ways to measure and evaluate implementation has been recognized by implementation researchers over time, and instruments for implementation research are continuously being developed and tested [29]. Still, the use of standardised and reliable instruments is not always feasible in the specific setting where implementation takes place.

\section{Methodological considerations}

This study has limitations that should be considered when interpreting the results. It was performed in one specific county in Sweden, where the implementation was initiated by the authorities, which may not be a situation that represents the whole country. The data collection where managers were interviewed face-to-face may have affected their answers, knowing that the interviewer was part of the implementation team. Self-reporting, as already discussed is also a method that may imply a limitation.

\section{Conclusions}

The implementation process was perceived as positive by the managers, who also find the new practices of medication review/medication report implemented in their clinics to a quite high extent. Implementation success, however, is not supported by registry data, showing the need for the development of reliable outcome measures for implementation.

\section{Supplementary information}

Supplementary information accompanies this paper at https://doi.org/10. 1186/s12913-020-05696-3.

Additional file 1.

Additional file 2.

Abbreviations

QIF: Quality Implementation Framework; P1-P10: Primary Care Unit 1-10; H1H21: Hospital clinic 1-21

Acknowledgements

Not applicable. 


\section{Authors' contributions}

SC, EM and CS were responsible for the conception and design of this work. SC and EM performed the data collection, SC analysed and interpreted the data and drafted the manuscript. EM and CS contributed to the final version of the manuscript, and SC, EM and CS, read and approved the final manuscript.

\section{Funding}

The study was supported by The Swedish Research Council for Health, Working life and Welfare, grant number 2014-4657 and Region Östergötland, Sweden. Author EM is currently employed by Region Östergötland, Sweden, and author CS was employed by Region Östergötland, Sweden during her participation in the study. Open Access funding provided by Linköping University Library.

\section{Availability of data and materials}

The datasets generated and analysed during the current study are available from the corresponding author on reasonable request.

\section{Ethics approval and consent to participate}

The study was performed as an evaluation of a quality improvement project in ordinary health care, which according to the Act in Swedish law concerning Ethical Review of Research involving Humans (SFS 2003:460) from the Ministry of Education and Cultural Affairs, is not subject for ethical approval. Written consent was deemed unnecessary according to the referenced national regulations. For the same reason, no administrative permissions were required to access and use the data/records described in the study. Agreement to take part in the structured interview, and responding to the survey, respectively, were considered consent to participate. The study included managers in health care, and registry data on group level, with no patients directly involved.

\section{Consent for publication}

Not applicable.

\section{Competing interests}

The authors declare that they have no competing interests.

\section{Author details}

'Department of Health, Medicine and Caring Sciences, Division of Community and Heath, Linköping University, SE-58183 Linköping, Sweden. ${ }^{2}$ Department of Clinical Pharmacology, Region Östergötland, SE-581 91 Linköping, Sweden. ${ }^{3}$ Centre for Healthcare Development, Region Östergötland, SE-581 91 Linköping, Sweden.

\section{Received: 27 May 2020 Accepted: 31 August 2020}

Published online: 14 September 2020

\section{References}

1. Bates DW, Singh H. Two decades since to err is human: an assessment of Progress and emerging priorities in patient safety. Health Aff (Millwood). 2018;37(11):1736-43. https://doi.org/10.1377/hlthaff.2018.0738.

2. Modig S, Lenander C, Viberg N, Midlöv P. Safer drug use in primary care - a pilot intervention study to identify improvement needs and make agreements for change in five Swedish primary care units. BMC Fam Pract. 2016;17(1):140.

3. Rostami P, Power M, Harrison A, Bramfitt K, Williams SD, Jani Y, Ashcroft DM, Tully MP. Learning from the design, development and implementation of the medication safety thermometer. Int J Qual Health Care. 2017;29(2):3019. https://doi.org/10.1093/intghc/mzw149.

4. WHO. The World Medicines Situation Report. 2011 Available at www.who. int/medicines/areas/policy/world_medicines_situation/en/ (accessed 15 March 2020).

5. Cadogan CA, Ryan C, Hughes CM. Appropriate Polypharmacy and medicine safety: when many is not too many. Drug Saf. 2016;39(2):109-16. https://doi. org/10.1007/s40264-015-0378-5.

6. Leendertse AJ, Egberts AC, Stoker $L$, van den Bemt PM. Frequency of and risk factors for preventable medication-related hospital admissions in the Netherlands. Arch Intern Med. 2008;168(17):1890-6. https://doi.org/10.1001/ archinternmed.2008.3.
7. Christensen M, Lundh A. Medication review in hospitalised patients to reduce morbidity and mortality. Cochrane Database Syst Rev. 2016;2: CD008986. https://doi.org/10.1002/14651858.CD008986.pub3.

8. Kwan JL, Lo L, Sampson M, Shojania KG. Medication reconciliation during transitions of care as a patient safety strategy: a systematic review. Ann Intern Med. 2013;158(5 Pt 2):397-403. https://doi.org/10.7326/0003-4819158-5-201303051-00006.

9. van Sluisveld N, Zegers M, Natsch S, Wollersheim H. Medication reconciliation at hospital admission and discharge: insufficient knowledge, unclear task reallocation and lack of collaboration as major barriers to medication safety. BMC Health Serv Res. 2012;12:170. https://doi.org/10.1186/1472-6963-12-170.

10. Midlöv P, Holmdahl L, Eriksson T, Bergkvist A, Ljungberg B, Widner $H$, Nerbrand C, Höglund P. Medication report reduces number of medication errors when elderly patients are discharged from hospital. Pharm World Sci. 2008;30(1):92-8.

11. Kramer JS, Hopkins PJ, Rosendale JC, Garrelts JC, Hale LS, Nester TM, Cochran P, Eidem LA, Haneke RD. Implementation of an electronic system for medication reconciliation. Am J Health Syst Pharm. 2007;64(4):404-22.

12. NBHW, National Board of Health and Welfare ( Socialstyrelsen). Ändring i föreskrifterna och allmänna råden (SOSFS 2000:1) om läkemedelshantering i hälso- och sjukvården [Changes in the provisions and general guidelines on medication management in health care]. In Swedish. Stockholm: Socialstyrelsen;2012.

13. Region Östergötland. Slutrapport Rätt läkemedel [final report: the right drug]. Linköping, Sweden: Region Östergötland; 2015. Available at: http:// vardgivarwebb.regionostergotland.se/pages/206591/Slutrapport.pdf (accessed 15 Feb 2020).

14. Meyers D, Durlak J, Wandersman A. The quality implementation framework: a synthesis of critical steps in the implementation process. Am J Community Psychol. 2012;50(3-4):462-80.

15. Proctor EK, Powell BJ, McMillen JC. Implementation strategies: recommendations for specifying and reporting. Impl Sci. 2013;8:139.

16. Ogrinc G, Davies L, Goodman D, Batalden P, Davidoff F, Stevens D. SQUIRE 2.0 (standards for QUality improvement reporting excellence): revised publication guidelines from a detailed consensus process. BMJ Qual Saf. 2016;25(12):986-92.

17. Hsieh H-F, Shannon SE. Three approaches to qualitative content analysis. Qual Health Res. 2009;15(9):1277-88.

18. Damschroder $\sqcup$, Aron DC, Keith RE, et al. Fostering implementation of health services research into practice: a consolidated framework for advancing implementation science. Impl Sci. 2009:4:50.

19. Logan J, Graham I. The Ottawa Model of Research Use. In Models and Frameworks for Implementing Evidenc-Based Practice: Linking Evidence to Action. Rycroft-Malone J, Bucknall T. (Eds). Oxford: Wiley-Blackwell;2010.

20. Mittman B. Implementation science in health care. In Brownson RC, Colditz GA Proctor EK, (Eds). Dissemination and implementation research in health: translating science to practice. New York; Oxford: Oxford University Press;2012.

21. Rycroft-Malone J. Promoting Action on Research Implementation in Health Services. In Rycroft-Malone J \& Bucknall T (editors). Models and frameworks for implementing evidence-based practice: Linking evidence to action. Oxford, UK: Wiley-Blackwell;2010.

22. Forsetlund L, Bjørndal A, Rashidian A, Jamtvedt G, O'Brien MA, Wolf F, Davis D, Odgaard-Jensen J, Oxman AD. Continuing education meetings and workshops: effects on professional practice and health care outcomes. Cochrane Database Syst Rev. 2009;2:CD003030.

23. Flodgren G, Parmelli E, Doumit G, Gattellari M, O'Brien MA, Grimshaw J, Eccles MP. Local opinion leaders: effects on professional practice and health care outcomes. Cochrane Database Syst Rev. 2011;8:CD000125.

24. Baker R, Camosso-Stefinovic J, Gillies C, Shaw EJ, Cheater F, Flottorp S, Robertson N, Wensing M, Fiander M, Eccles MP, Godycki-Cwirko M, van Lieshout J, Jäger C. Tailored interventions to address determinants of practice. Cochrane Database Syst Rev. 2015;4.

25. Ryan RM, Deci EL. Self-determination theory and the facilitation of intrinsic motivation, social development, and well-being. Am Psychol. 2000;55(1):68-78.

26. van der Weijden $T$, Wensing $M$, Eccles $M$, Grol R. Feedback and reminders. In Grol R, Wensing M, Eccles M, Davis D (Editors). Improving patient care. $2^{\text {nd }}$ Edition. Oxford; Wiley-Blackwell:2013.

27. Latkin CA, Edwards C, Davey-Rothwell MA, Tobin KE. The relationship between social desirability bias and self-reports of health, substance use, and social network factors among urban substance users in Baltimore Maryland. Addict Behav. 2017;73:133-6. 
28. Proctor E, Silmere H, Raghavan R, Hovmand P, Aarons G, Bunger A, Griffey R, Hensley M. Outcomes for implementation research: conceptual distinctions, measurement challenges, and research agenda. Admin Pol Ment Health. 2011;38:65-76

29. Lewis CC, Stanick CF, Martinez RG, Weiner BJ, Kim M, Barwick M, Comtois KA. The Society for Implementation Research Collaboration Instrument Review Project: a methodology to promote rigorous evaluation. Impl Sci. 2015;10:2

\section{Publisher's Note}

Springer Nature remains neutral with regard to jurisdictional claims in published maps and institutional affiliations.

- fast, convenient online submission

- thorough peer review by experienced researchers in your field

- rapid publication on acceptance

- support for research data, including large and complex data types

- gold Open Access which fosters wider collaboration and increased citations

- maximum visibility for your research: over $100 \mathrm{M}$ website views per year

At BMC, research is always in progress. 